\title{
Internal Condition Analysis on Tourism Development of Bintan Regency 2019
}

Indonesian Journal of Tourism and Leisure, 2021
Vol. 02 (1), 51-61
(C) The Journal, 2021
DOI: $10.36256 /$ ijtl.v2i1.129
https: / /journal.lasigo.org/index.php/IJTL
Article History
Received: March $3^{r d}, 2021$
Revised: April $27^{t h}, 2021$
Accepted: April 29 $29^{2 h}, 2021$

\section{Rezky Feni Oktaviana}

Program Studi Administrasi Negara, FISIP, Universitas Maritim Raja Ali Haji, Kepulauan Riau, Indonsia Email: riski52626@gmail.com

\section{Adji Suradji Muhammad}

Program Studi Magister Administrasi Publik, FISIP, Universitas Maritim Raja Ali Haji, Kepulauan Riau, Indonsia Email: suradji@umrah.ac.id

\section{Fitri Kurnianingsih}

Program Studi Magister Administrasi Publik, FISIP, Universitas Maritim Raja Ali Haji, Kepulauan Riau, Indonsia Email: fitrikurnianingsih@umrah.ac.id

\section{Mahadiansar Mahadiansar}

Pascasarjana Ilmu Administrasi Publik, FIA, Universitas Brawijaya, Kota Malang, Jawa Timur Email: mahadiansar@student.ub.ac.id

\begin{abstract}
The dynamics of tourism as an economic driver will greatly affect the environment in tourism development in Bintan Regency. One of the influencing environment is the internal condition in tourism management which is the reason for the need to map the problem. This paper focuses on environmental studies of the community, private sector, local government in the internal tourism of Bintan Regency in 2019. The research uses a literature study using secondary data which is analyzed in depth. The results showed that the internal analysis of tourism which includes 3 main components of tourism development, namely sustainable improvement of the tourism industry, improving institutional quality both in vertical agencies and the role of local communities which is very important in developing tourism in Bintan Regency. With the existence of three main components in the analysis of the internal environment for tourism in Bintan Regency, it is hoped that it can have a positive impact in a sustainable manner.
\end{abstract}

Keywords: Internal Analysis; Tourism Development; Bintan

\section{Introduction}

Tourism development can be carried out by the country itself, but also through cooperation in order to get more benefits and support considering the existence of cooperation between two or more countries in achieving the same goal, one of which is through diplomacy (Widhasti et al., 2017). Stated that tourism sector diplomacy is an instrument used by relations between one country and another as part of public diplomacy, with this diplomacy is one of the soft power 
instruments (Minardi et al., 2020). According to Mathieson \& Wall (1982) Tourism is a series of activities in the form of temporary movement of people to a destination outside their place of residence or workplace, activities they carry out while living in that destination and the facilities provided to meet their needs both during on the way or at their destination. Tourism diplomacy has many channels of diplomacy between governments, government to non-governmental organizations, or government to individuals, or vice versa, in various ways. Based on Law Number 10 of 2009 concerning Tourism, tourism development is carried out based on the principles of benefit, kinship, fairness and equality, balance, independence, sustainability, participatory, sustainable, democratic, equality and unity. Furthermore, this principle is also for the realization through the implementation of a tourism development plan by taking into account the diversity, uniqueness, and uniqueness of culture and nature, as well as human needs for tourism.

The attractiveness of Indonesia's tourism sector has brought tourists from various countries in the world. Indonesian tourism has indeed become one of the destinations that are in high demand by many tourists because there is natural beauty in it. The huge potential of Indonesian tourism has made many foreign tourists come to Indonesia (Kurniawan et al., 2019). From 2014 to 2019 , it is noted that foreign tourists who come to Indonesia have always increased every year. Tourism as a sector has played an important role in economic development. Increasingly progress and welfare have made tourism a major part of human needs or lifestyle and moved millions of people to get to know nature and culture to other parts of the world or areas of the world. The movement of millions of people then moves the interconnected economic chain to form a service industry that makes an important contribution to the economy, as well as an increase in economic welfare at the local community level. In the history of development in Indonesia, the strategic role of tourism in contributing to foreign exchange earnings, regional income (PDRB), as well as improving the welfare of the community, especially through; absorption of labor, increasing income, and growing business fields cannot be denied their existence.

Trend data from the last five years have provided significant evidence of improved performance in the tourism sectors (Pradana, et al., 2020). The success of the tourism sector so that it is able to become one of the leading sectors in an area really needs management that is appropriate and appropriate to the characteristic conditions of the region, Because management in developing tourist areas must be interconnected and supportive between sectors (Abdurahman, 2014). Tourism in Bintan Regency cannot accelerate from its strategic position with Singapore, the position Bintan Island is located at the intersection between Singapore-Malaysia and the island of Sumatra, in the Riau Islands allowing Bintan to have high tourism potential and become a busy area visited by travelers from Asia, Europe, and tourists. domestic. Therefore, the development of the Bintan Regency is expected to provide a balance of tourism growth in Indonesia and make this area one of the growth poles for tourism development in the western region of Indonesia (Muzdalifah, 2019). Furthermore, efforts to develop tourism destinations as the main element in attracting tourist visits to Indonesia need to be implemented systematically, with the support of reliable marketing, development, and tourism industry development to strengthen the development of existing tourism destinations Bintan Island offers a variety of tourist objects that you can visit when visiting this beautiful island. Bintan Resort is the main destination for tourists. It is a place that has a beautiful beach covering an area of 23,000 hectares. White sand and facing the South China Sea, this beach offers a million attractions for tourists, such as swimming, fishing, snorkeling, surfing, diving, banana boat, flying fish, kayaking, adventure, and enjoying ecotourism. It doesn't stop at Bintan Resort, there is still a myriad of natural collections that are kept by Bintan Island.

Then, you will feel the aroma of past civilizations again enter its historical tourist sites. In line with the increasingly competitive development of the tourism industry and increasingly dynamic world market trends, the tourism development in Bintan Regency must be encouraged to develop 
more strongly and be directed appropriately to increase the comparative advantage and competitive advantage of tourism in Bintan Regency. The purpose of this study is to identify strategic issues and problems in the local, regional context that are faced and related directly or indirectly to tourism development in Bintan Regency, and map conditions, the level of development of existing tourism destinations, and the main problems faced. The renewal in this research is tourism to strengthen institutional capacity by emphasizing the influencing factors in the organizational environment both from local governments and local communities, this study was carried out so that cooperation between stakeholders can get an inclusive picture in the development of the sustainable tourism sector.

\section{Literature Review}

According to Guyer Flauler (2009) states that tourism is a phenomenon based on the need for health and change of air, a conscious assessment \& fostering love for natural beauty, is also basically caused by the increasing association of various nations and human classes as a result of the development of commerce, industry, as well as improvements of transportation equipment. different from Koen Meyers (2009) which states that tourism is a travel activity that is carried out temporarily from the original place of residence to the destination with the reason not to settle down or earn a living but only to fulfill curiosity, spend free time or holidays and other purposes. The tourism industry can be defined as a set of business fields that produce various services and goods needed by those who travel on a tour.

According to Medlik (1987), every product, both real and virtual which is presented to meet certain human needs, should be assessed as an industrial product (Pender \& Sharpley, 2005). If a multitude of unified products exists between various companies and organizations in such a way as to characterize their overall function and fulfill them in Inonn's life, the industry should be considered an industry (Bhatia, 2006). As stated by UNWTO (United Nations World Tourism Organization) in the International Recommendations for Tourism Statistics 2008, the Tourism Industry includes; Accommodation for visitors, Food and beverage service activities, passenger transportation, travel agents and other reservation activities, cultural activities, sports, and entertainment activities. UNWTO is a World Tourism Agency under the auspices of the United Nations. According to the Tourism Law No.10 of 2009, the Tourism Industry is a collection of tourism businesses that are interrelated in order to produce goods and/or services to meet the needs of tourists in the administration and implementation of tourism (Chow, Ling, Yen, \& Hwang, 2017; Ratman, 2016). The Tourism Industry can be defined as a set of business fields that produce various services. and items needed by those traveling on a tour. The scope of the tourism industry concerns various economic sectors. The aspects covered in the tourism industry include:

- Restaurant. In the restaurant sector, attention can be directed, among other things, to the quality of service, both in terms of types of food and service techniques. In addition, in terms of nutritional content, food health, and restaurant environment as well as the discovery of new and traditional foods, both recipes, ingredients, and their presentation, which can be developed nationally, regionally, and even internationally (Pujilestari et al., 2018; Ramintang \& Pangemnan, 2016; Violina \& Suryawan, 2016).

- Lodging. Lodging or homestay, which consists of hotels, motels, resorts, condominiums, time-sharing, guest houses, and bed and breakfasts, are aspects that can be accessed in the development of the tourism sector. The things that need to be considered in the development of this inn can be in the form of; marketing strategy, onsite service, integration, and restaurant or travel agency, and so on. Research can also be directed at efforts to reduce waste from the tourism industry (Sulartiningrum, et al., 2018; Wilopo \& Hakim, 2017).

- Travel services. Includes travel agents, tour packages (tour wholesalers), incentive travel companies, and reception services (Hamzana, 2018; Rahmandika et al., 2020). 
- Transportation. This can be in the form of tourist transportation facilities and infrastructure such as cars/buses, airplanes, trains, cruises, and bicycles (Fadilla \& Darmawan, 2018; Sitorus \& Sitorus, 2017).

- Development of Tourist Destination Areas. This can be in the form of market and share research, the feasibility of tourist areas, building architecture, and engineering, as well as financial institutions (Setiawan, 2016).

- Recreation Facilities. Covering the development and utilization of State parks, camping grounds, concert halls, theaters, and others (Utama, 2015).

- Tourist attractions. Includes theme parks, museums, protected forests, agro-tourism, natural wonders, arts and cultural activities, and so on (Putra, 2013).

\section{Method}

The research method used is library research, by conducting searches of several library sources such as e-books, journals, websites, organizational reports, and other documents both printed and online that are relevant to the topic being studied in the study (Khatibah, 2011). A literature study is a series of activities related to methods of collecting library data, reading, and taking notes, and managing research materials (Zed, 2014). This study, using documentation data collection techniques from various reputable journal references, e-books related to tourism in Bintan Regency. The data analysis technique in this research is content analysis (Ridley, 2008).

\section{Result and Discussion}

\subsection{Vision and Mission of Bintan Regency}

The Bintan Regency vision for Tourism Development in the Bintan Regency Regional Tourism Development Plan for 2015-2025 is: The realization of Bintan as a World Class Tourist Destination that is Highly Competitive, Sustainable, and Capable of Encouraging Regional Development and Improving Community Welfare. These, namely world-class, competitive, sustainable tourist destinations, encouraging regional development and increasing welfare are as follows Realizing world-class tourism destinations means developing tourism destinations that have uniqueness and distinctiveness with local character and wisdom that has an international flavor; Has services that meet international standards; Able to attract foreign and domestic tourists to come to visit; Provide high value and satisfaction for tourists, and Lifting the dignity of the nation in the world and become national pride.

Competitive tourism destinations, which are intended as the relative ability of a tourism destination compared to its competitors at the international level to meet needs, become choices and attract potential tourists to come for a tour. This capability is determined by the specific factors of tourism, namely attractions or attractiveness, and general factors, namely including facilities, infrastructure, and supporting facilities. Sustainable tourism destinations must be the basic principles that are adhered to. The principle of developing tourism destinations based on sustainable development rests on 4 (four) main aspects, namely: Environmentally Sustainable the development of national tourism destinations that are environmentally friendly and capable of protecting, protecting, and preserving natural resources (environmental conservation and protection).

1. Socio-cultural sustainability (Socially Culture Sustainable) - the development of tourism destinations that are able to maintain and improve the quality of local social and cultural values. This includes efforts to mitigate negative impacts that affect social and cultural life;

2. Economic sustainability (Economically Sustainable) - the development of national tourism destinations must be able to maintain economic continuity and growth by developing and providing business and employment opportunities; 
3. Institutional sustainability - the development of national tourism destinations must be able to develop institutional cooperation, creative, productive and mutually beneficial partnerships between the government, society, and the private sector.

4. Encouraging regional development, in the context of this vision, is defined as the development of potential-based destinations owned by each region that can provide a high multiplier effect and are able to move the development chain in the area.

Tourism Destinations to increase community welfare, mandating efforts to empower the community through strengthening and enhancing the capacity, role, and initiative of the community as a stakeholder. The community is not an object but must be positioned as a subject in the development of national tourism destinations so that people get a large value of benefits (both economic, social, and cultural) so that the quality of life and welfare of the community increases in line with the development of tourism destinations. In addition, the wisdom possessed by the community will strengthen the competitiveness of a destination.

\subsection{International-based Bintan Tourism Event}

In 2019, Bintan recorded two agendas plus one event that masks the 10 National Events, namely Bintan Ironman 70.3. Meanwhile, the other two Bintan events are Bintan Triathlon and Tour de Bintan. Meanwhile, other Kepri tourism agendas that are included in the national tourism agenda are the Batam International Culture Carnival, Penyengat Island Festival, Kepri Maritime Festival and Kenduri Seni Melayu. The addition of the number of Kepri Province tourism agendas proposed to the national tourism agenda was carried out considering the many extraordinary tourism potentials of the Riau Islands. Plus the increase in the number of tourist visits to this area which always has a significant increase from year to year.

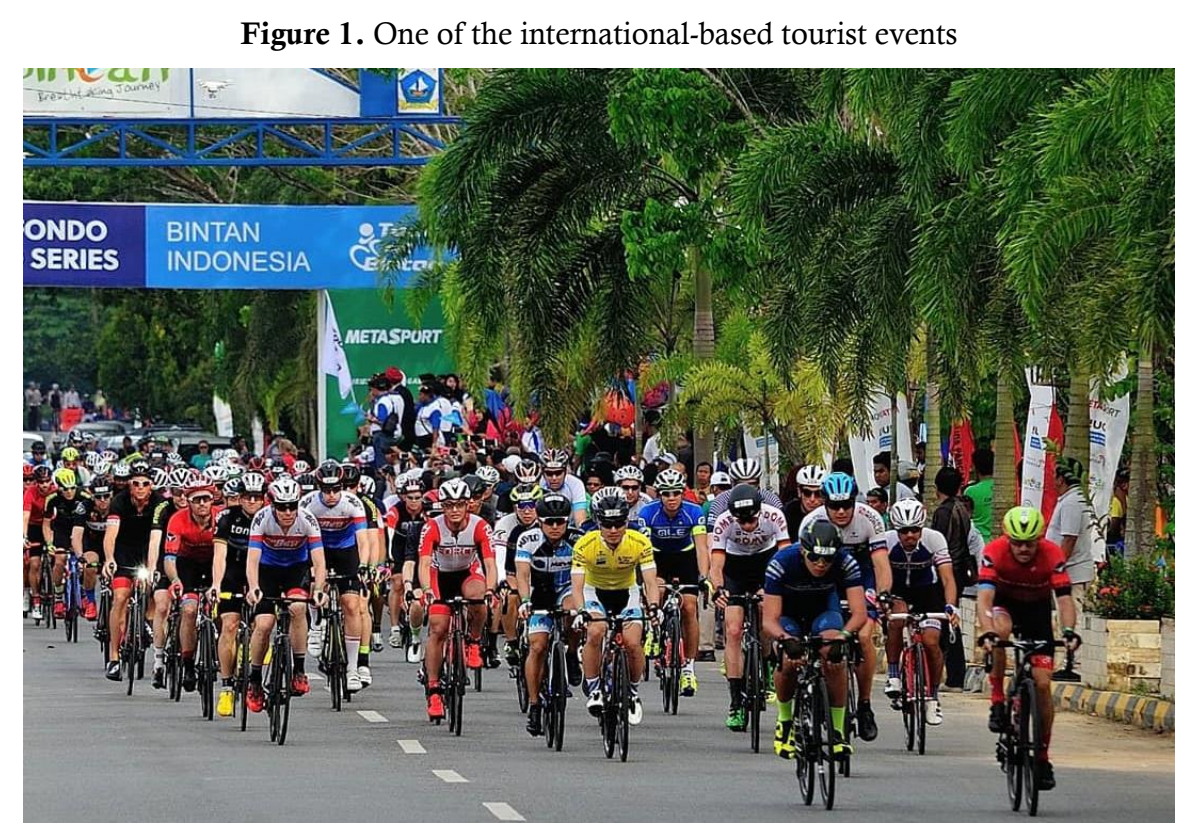

Source: Departement of Tourism and Culture District of Bintan (2019)

The twelve tour agendas are the Kepri Maritime Festival (FBK), Tour De Kepri, Tour De Bintan, Ironman Bintan, Bintan Triatlon, Dragon Boat Race, Lion Dance Festival, Kenduri Seni Batam, Penyengat Island Festival, Year-end Kenduri Festival, Dangkong Festival, and the Carang River Festival. There are three agendas proposed from Bintan Regency, namely Tour De Bintan, Ironman Bintan and Bintan Triatlon. As is known, the three international scale sport tourism events have always succeeded in bringing thousands of tourists both foreign and domestic to the Bintan area. So that it is always included in the tourism agenda that is proposed 
to be the national tourism agenda. The National Tourism Agenda is a tourism agenda selected by the Indonesian Ministry of Tourism from around three thousand local tourism events throughout Indonesia into 100 main Indonesian tourism agendas which are then recorded in the Indonesian Tourism Guide Book.

This tourism agenda is arranged sequentially from Aceh Province to Papua Province. This tourism agenda is known as Wonderful Indonesia and is being promoted by the Ministry of Tourism with various strategies with the aim of increasing the number of tourist visits to Indonesia. The inclusion of Bintan in Indonesia's national tourism agenda is also expected to be able to increase the number of tourist visits to this area, making Bintan a favorite destination for tourists visiting Indonesia and ultimately increasing income for this region in particular and for the country in general.

\subsection{Conditions of Tourism Industry in Bintan District}

The dominance of tourism business development is still concentrated in the Lagoi area which is closed system, this is because the Lagoi area has developed a tourism business based on international class hotels and resorts. The tourism business based on star hotels and resorts in the Lagoi Region is located along the beautiful beaches of Bintan, directly opposite Singapore and Malaysia, and is equipped with luxurious facilities. This is what makes the Lagoi area the main attraction for foreign tourists to come to Bintan. The development of tourism businesses in the Lagoi area needs to be supported by strengthening other tourism businesses, such as tourist attraction businesses, tourism transportation service businesses, tourism travel service businesses, food and beverage service businesses, entertainment and recreation activities, etc (Holloway \& Humphreys, 2016).

Figure 2. Tourism Industry Chain

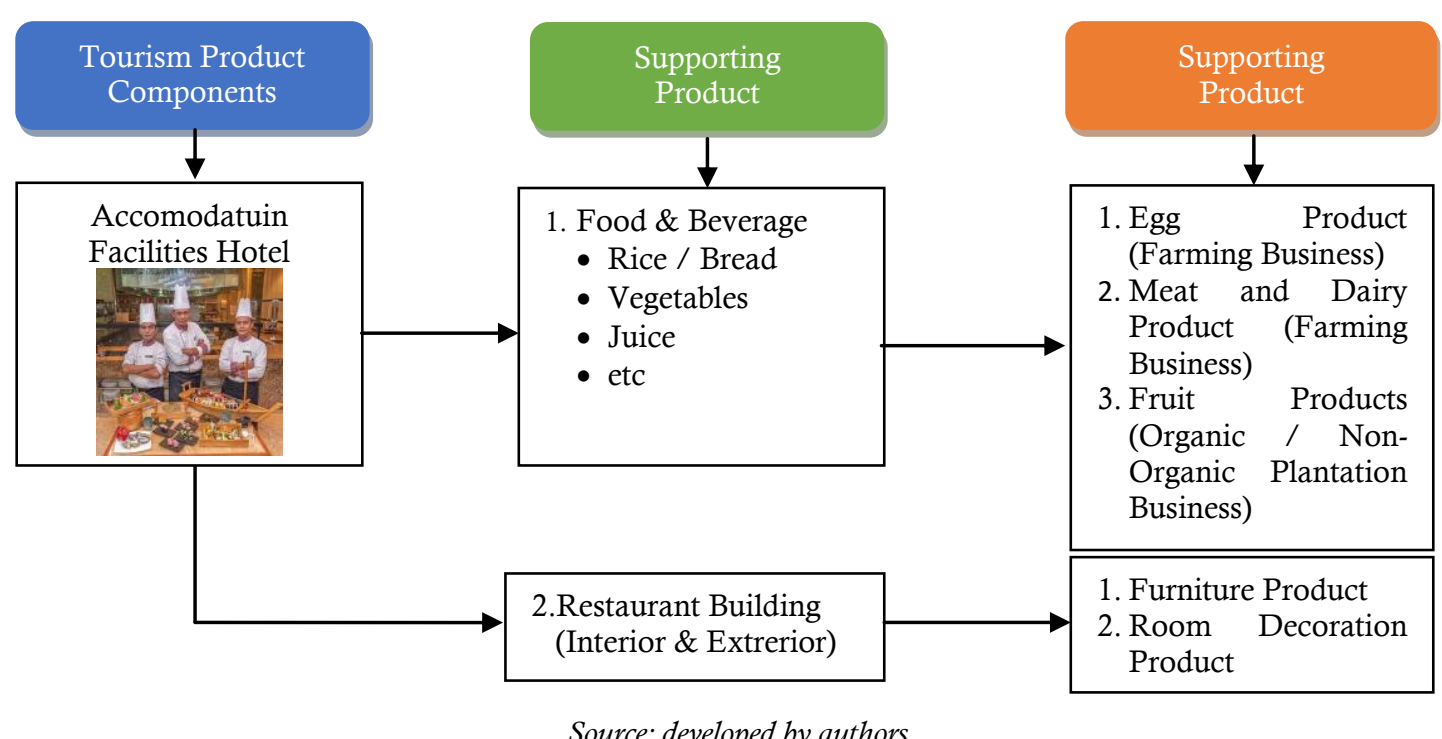

Furthermore, the not optimal capacity, quantity, and operational network of the tourism product chain, the need for synergy between the chains that form the tourism industry in Bintan Regency still needs to be developed. Potential local resources, such as agricultural products, livestock, fisheries, handicrafts, have not been utilized by the tourism industry in Bintan. By utilizing the local potential, it will provide added value for tourism products. tourism is a sector that consists of very many industries and has very broad linkages with other fields. By strengthening the synergy between the chain forming the tourism industry in Bintan, it is hoped 
that more people/residents will feel the benefits of the growing tourism industry in Bintan, either directly, indirectly, or in part.

Then the potential for community businesses that have not been optimally developed and have access to tourism businesses, is because the tourism business partnership in Bintan is still not seen to be running optimally. The tourism industry in Bintan still seems to be running independently, not yet showing any cooperation with one another. Therefore, the partnership patterns between tourism businesses, as well as tourism businesses and other business actors in Bintan, still need to be improved. Forms of partnerships that can be done, for example, cooperation in developing tourist attractions, cooperation in promotion and marketing, etc.

There is a lot of environmental degradation caused by Mining Activities and the Processing Industry or mainly Bauxite (Pratiwi, et al., 2019). This can be seen in mining and excavation activities, as well as the processing industry in Bintan Regency, which has an impact on environmental damage in Bintan Regency, such as river water pollution by industries, open puddles of former bauxite mining, deforestation, etc. Several parties have made efforts to preserve and improve the natural and socio-cultural environment, but still, need to be improved. Therefore, it is necessary to be supported by the involvement of all parties in efforts to conserve and improve the environment in Bintan, such as the Government, industry players, and miners, as well as the community itself.

\subsection{Institutional Quality Improvement}

Coordination and synergy that is cross-sectoral and cross-sectoral in the tourism business still need to be developed, this is very much needed because the tourism sector has a high intensity of relations and linkages with other fields or sectors, both cross-sectoral and cross-regional (Sentanu \& Mahadiansar, 2020). Relationships in cross-sectoral contexts, among others, are related to the forestry, marine, agricultural, and plantation sectors, industry and trade, telecommunications, transportation, environment, culture, education, immigration, and foreign relations, and other related sectors or fields. This relationship includes aspects of resource utilization, support for infrastructure and facilities, human resource support, policy support for ease of licensing, investment, and other forms of regulation. As a sector that has very high linkages, tourism development requires very intensive coordination and integration of policies to support the achievement of the vision and mission of tourism development as a mainstay of national development, both in order to accelerate the increase in tourist visits to increase foreign exchange earnings and to contribute to the economy for the region.

In encouraging community empowerment efforts. Coordination between the government and institutions at the community level, the lack of a system of coordination between the government and institutions at the community level results in insufficient business and employment opportunities in the tourism sector (Mahadiansar \& Aspariyana, 2020). With this condition, there is an inequality in the tourism business sector. In accordance with these problems, the government needs to create a mediator that bridges the government and the community. Mediators can be in the form of non-governmental organizations, universities, or government agencies to social programs or policies in the tourism sector. However, public understanding of the positive impacts of tourism development needs to be improved as a change in the national development paradigm from efforts to achieve growth to equitable distribution of development results at the regional level, as well as the anticipation of the implementation of regional autonomy has provided new challenges to explore more potential, opportunities owned by the District Bintan.

One of the factors that can encourage the involvement of the Bintan Regency community in tourism development and development is the creation of a positive perception from the community towards the positive impact of the development of the tourism sector. So that no 
negative things arise, especially those related to the added value aspects that the tourism sector is able to provide to the economy of the people around the tourist areas. For example, increasing the activity of the tourism sector in an area will create jobs for the local population, will increase the income of the community and government, and will also encourage regional development, especially around the tourism area.So that the awareness of the Bintan community needs to be raised through various socialization, and followed up with efforts to prepare the community to seize opportunities for developing the tourism sector. For example, among others, contributing to creating a conducive atmosphere for tourists to travel around their residence by taking part in maintaining the safety and comfort of tourists. In an effort to make the tourism sector the leading sector of Bintan, increasing the role of the community both as actors and beneficiaries needs to be put forward.

\subsection{The Role of Local Communities in Tourism Development}

The involvement and role of local communities in tourism development needs to be increased in tourism activities (Firdaus, et al., 2019; Pratiwi et al., 2019). It is very different, depending on the type of potential, experience, knowledge and expertise possessed by the local community. In this case, the potential and position of local communities as important actors or subjects in tourism development need to be optimized, including: (1) increasing the number of tourism operators managed by local communities, (2) increasing the value of land functions utilized by local communities in the tourism sector. (3) increasing community participation as hosts in the tourism sector, (4) increasing the involvement of local communities in the tourism industry which is managed by the private sector. Tourism management must use the concept of community-based tourism development through empowerment programs. Community empowerment is a deliberate effort to facilitate local communities in planning, deciding, and managing their local resources through collective action and networking so that in the end they have the ability and independence economically, ecologically and socially.

In a broader sense, community empowerment is a facilitation process to encourage people to be able to position themselves proportionally and to become the main actors in utilizing their strategic environment to achieve sustainable prosperity in the long term. Local communities must be actively involved in tourism development. Furthermore, tourism is also expected to provide opportunities and access for local communities to develop tourism support businesses such as handicraft shops, souvenir shops, food stalls, etc. so that local people get better economic benefits and are obtained directly from tourists to improve their welfare and standard of living. The actualization of the concept of awareness of tourism in tourism destinations is very important because the community, as an important part of tourism development activities, has a strategic role not only as a beneficiary of development benefits, but also as an actor for the success of tourism development in their respective regions. One of the important and fundamental aspects for the success of tourism development is the creation of a conducive climate for the growth and development of tourism activities in an area.

This becomes possible if it has the support, acceptance and participation of the local community. In the context of support and participation, the Ministry of Tourism and Creative Economy has introduced the concept of "Tourism Awareness" which is defined as "a concept that describes community participation and support in encouraging the creation of a climate conducive to the growth and development of tourism activities in a place / region". This definition positions the community as the host (host). Apart from being the host, the community also acts as a tourist (guest). Here the role of the community is expected to be able to recognize Indonesia's tourism potential, as well as move the tourism chain in its region. Aware of tourism as a form of commitment to support tourism development, in fact, it is not yet rooted, understood, and addressed in an appropriate and concrete manner by the community. Several 
things that indicate this include the limited understanding of the community towards tourism and tourism awareness (including sapta charm) which results in attitudes and behavior of people who do not care about tourism. This can be seen in the attitudes and behavior of people who are offensive / aggressive towards tourists in offering products and services, the ODTW environment is dirty, unorganized, and does not provide a comfortable atmosphere for tourists. In addition, support for incentives and facilities from both government and private institutions for people who are going to travel is still limited.

Figure 3. Potential of tourism village by Anculai village community, Bintan district

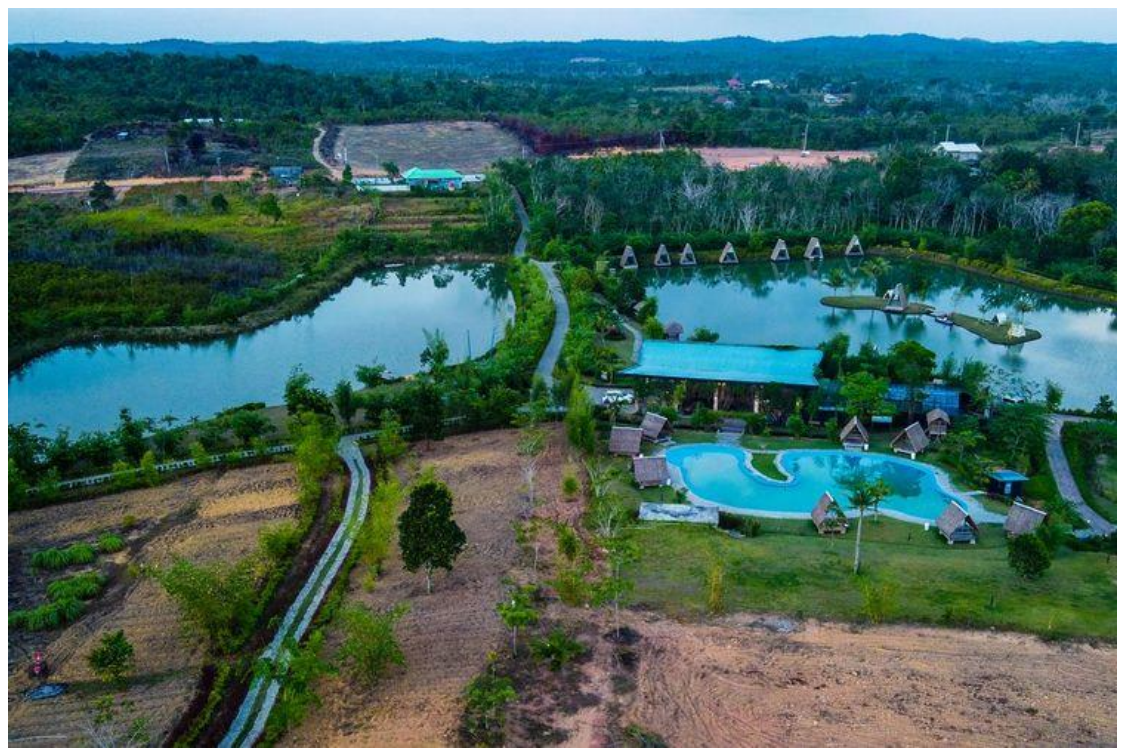

Source: Kompas.com (2021)

\section{Conclusions}

The tourism industry will greatly impact the development of tourism businesses that have international potential in the Bintan Regency. The tourism potential of Bintan that can be developed is of course increasing opportunities by focusing on increasing the quality and diversity of tourism business products as well as improving the facilitation, regulations, and incentives for the development of tourism businesses in Bintan Regency. In addition, improvements in tourism institutions in the internal conditions in Bintan Regency must prepare tourism education institutions where the position of tourism resorts as "foster parents" and an adequate apprenticeship location to improve the human resources of the Bintan Regency community. By strengthening the institution, there will certainly be the development of new resorts by foreign investors, so that cooperation efforts between resorts and tourism educational institutions with the "foster parents" program and providing scholarships to students through partnerships for channeling human resources in the tourism sector in Bintan Regency.

\section{Acknowledgment}

We thank the Bintan district government for providing information in the form of secondary data in the form of the Bintan Regency Regional Tourism Development Master Plan in 2019

\section{Funding}

This research received no external funding

\section{Conflicts of Interest}

The author declare no conflict of interest 


\section{References}

Abdurahman, B. (2014). Destination Management Organization (DMO): Diskursus Konsep Dasar Tata Kelola Kawasan Parawisata dalam Konteks Collaborative Gevernance di Indonesia. Jurnal Kepariwisataan Indonesia, 9(2), 1-21.

Bhatia, A. K. (2006). International Tourism Management. Sterling Publishers Pvt.Ltd.

Chow, H., Ling, G.-J., Yen, I., \& Hwang, K.-P. (2017). Building Brand Equity Through Industrial Tourism. Asia Pacific Management Review, 22(2), 70-79. https://doi.org/10.1016/j.apmrv.2016.09.001

Dinas Kebudayaan dan Pariwisata Bintan. (2019). Siap-siap, Tour de Bintan 2019 Kembali Hadir.

Fadilla, D. N., \& Darmawan, F. (2018). Pramuka Island Tourism Accessibility Transportation Development of The Thousand Island. Journal of Tourism Destination and Attraction, 6(2), 115.

Firdaus, F., Shalihin, N., Anggreta, D. K., Yasin, F., \& Tutri, R. (2019). Improving The Benefits of Karamba Into Tourism Activities: An Effort To Reduce The Ecological Impact Of Aquaculture In Maninjau Lake, Indonesia. GeoJournal of Tourism and Geosites, 26(3), 726736. https://doi.org/10.30892/gtg.26304-392

Flauler, G. (2009). Handbuch del weizerischen Volkswirtchaft.

Hamzana, A. A. (2018). Pelaksanaan Standarisasi Pelayanan Pariwisata Halal dalam Pengembangan Pariwisata di Nusa Tenggara Barat. Pena Justisia: Media Komunikasi Dan Kajian Hukum, 17(2), 1-16. https://doi.org/10.31941/pj.v17i2.545

Holloway, J. C., \& Humphreys, C. (2016). The Business of Tourism (10th ed.). Lon: Sage Publications Ltd.

Khatibah, K. (2011). Penelitian kepustakaan. Jurnal Iqra', 5(01), 36-39.

Kompas.com. (2021). Desa Wisata Anculai di Bintan, Salah Satu Desa Wisata Terbaik di Indonesia.

Kurniawan, F., Adrianto, L., Bengen, D. G., \& Prasetyo, L. B. (2019). The social-ecological status of small islands: An evaluation of island tourism destination management in Indonesia. Tourism Management Perspectives, 31, 136-144. https://doi.org/10.1016/j.tmp.2019.04.004

Mahadiansar, M., \& Aspariyana, A. (2020). PEST Analysis Model dalam Pengembangan Potensi Wisata Pulau Benan, Kabupaten Lingga, Kepulauan Riau. Indonesian Journal of Tourism and Leisure, 1(1), 14-25. https://doi.org/10.36256/ijtl.v1i1.93

Medlik, S. (1987). Tourism: Past, Present, and Future. London.

Meyers, K. (2009). Pengertian Pariwisata. Jakarta: Unesco Office.

Minardi, A., Taufik, T., Afriantari, R., \& Hasanah, N. U. (2020). Indonesian Tourism Diplomacy to India. Indonesian Journal of Tourism and Leisure, 1(1), 1-13. https://doi.org/10.36256/ijtl.v1i1.83

Muzdalifah, H. (2019). Strategi Badan Penanaman Modal dan Promosi Daerah dalam Meningkatkan Investasi Bidang Parawisata di Kabupaten Bintan Provinsi Kepulauan Riau (Studi di Badan Penanaman Modal dan Promosi Daerah). Universitas Muhammadiyah Malang.

Pender, L., \& Sharpley, R. (2005). The Management of Tourism. London: SAGE Publications Ltd. https://doi.org/10.4135/9781446214961

Pradana, C. S., Iban, C., \& Setyastama, R. (2020). Tourism Impact On Conservation And Utilization Of Borobudur Temple After Being Declared As Ten New Bali Tourist Destination In Indonesia. Journal of Indonesian Tourism and Development Studies, 8(2), 79-84. https://doi.org/10.21776/ub.jitode.2020.008.02.03

Pratiwi, K. R. I., Saleh, C., \& Sentanu, I. G. E. P. S. (2019). Policy Implementation of Tour Guides License in Maintaining the Quality of Tourism in Bali Province. Journal of Indonesian $\begin{array}{llll}\text { Tourism and Development } \quad \text { Studies, } & 7(3), & 175-183 .\end{array}$ https://doi.org/10.21776/ub.jitode.2019.007.03.06

Pujilestari, S., Amelia, J. R., \& Romadhan, M. F. (2018). Potensi Wisata Gasronomi Halal di Wilayah Pecinan, Petak 9, Glodok Jakarta. Juenal Industri Pariwisata, 1(2), 114-124.

Putra, T. R. (2013). Peran Pokdarwis dalam Pengembangan Atraksi Wisata di Desa Wisata Tembi, Kecamatan Sewon-Kabupaten Bantul. Jurnal Pembangunan Wilayah Dan Kota, 9(3), 
225-235. https://doi.org/10.14710/pwk.v9i3.6522

Rahmandika, Y. F., Puji, L., \& Purwanto, H. (2020). Analisis Pengaruh Harga dan Kualitas Pelayanan Terhadap Kepuasan Konsumen. EKOBIS : Jurnal Ilmu Manajemen Dan Akuntansi, 8(1), 65-74. https://doi.org/10.36596/ekobis.v8i1.319

Ramintang, J., \& Pangemnan, S. (2016). The Application of Activity-Based Costing (ABC) and Job Order Costing (JOC) Wisata Bahari Restaurant Manado. Jurnal Emba, 4(1), 1-10.

Ratman, D. R. (2016). Pembangunan Destinasi Parawisata Prioritas 2016-2019. Akselarasi Pembangunan Keparawisataan Dalam Rangka Pencapaian Target12 Jyta Wisman Dan 260 Juta Wisnus 2016. Jakarta.

Ridley, D. (2008). The Literature Review: A Step-by-Step Guide for Students. London: Sage Publications Ltd.

Sentanu, I. G. E. P. S., \& Mahadiansar. (2020). Memperkuat Peran Pemerintah Daerah: Mengelola Pariwisata Lokal Yang Berkelanjutan. Jurnal Ilmu Administrasi Negara (JUAN), 8(1), 1-20. https://doi.org/10.31629/juan.v8i1.1879

Setiawan, R. I. (2016). Pengembangan Sumber Daya Manusia di Bidang Pariwisata: Perspektif Potensi Wisata Daerah Berkembang. Jurnal Penelitian Manajemen Terapan (Penataran), 1(1), 23-35.

Sitorus, B., \& Sitorus, C. N. (2017). Peran Transportasi dalam Mendukung Kawasan Strategis Pariwisata Nasional Danau Toba. Jurnal Manajemen Transportasi \& Logistik, 04(01), 9-24.

Sulartiningrum, S., Nofiyanti, F., \& Fitriana, R. (2018). Pelatihan Peningkatan Kualitas SDM Bidang Pariwisata di Desa Wisata Cikolelet Serang Banten. Jurnal SOLMA, 7(2), 176-181. https://doi.org/10.29405/solma.v7i2.2228

Utama, I. G. B. R. (2015). Pengantar Industri Parawisata. Yogyakarta: Deepublish.

Violina, S., \& Suryawan, I. B. (2016). Kualitas Kebersihan Lingkungan sebagai Penunjang Daya Tarik Wisata Pantai Sanur Raja. Jurnal Destinasi Parawisata, 4(1), 20-25. https://doi.org/10.24843/JDEPAR.2016.v04.i01.p04

Widhasti, G. B., Damayanti, C., \& Sardjono, H. S. (2017). Diplomasi publik pemerintah republik Indonesia melalui pariwisata halal. Solidaritas : Jurnal Ilmu-Ilmu Sosial, 1(1), 1-13.

Wilopo, K. K., \& Hakim, L. (2017). Strategi Pengembangan Destinasi Pariwista Budaya (Studi Kasus pada Kawasan Situs Trowulan sebagai Pariwisata Budaya Unggulan di Kabupaten Mojokerto). Jurnal Administrasi Bisnis (JAB), 41(1), 56-65.

Zed, M. (2014). Metode Penelitian Kepustakaan (3rd ed.). Jakarta: Yayasan Obor Indonesia. 